\title{
THE RELATION OF ECONOMIC CONDITIONS TO THE CAUSES OF CRIME.
}

"The destruction of the poor is their poverty."-Proverbs $x$. 15.

The criminologist, in his search for the causes of crime, cannot, in the nature of things, accept any blanket theory. The fall of man and the doctrine of total depravity may satisfy his theological views as to the origin of evil, but they cannot satisfy his sociological views. He must, as a criminologist, be able to develop specific causes more or less in harmony with his theology. He cannot be a criminologist without being scientific. He must study anthropology-the biology of the human race-and through this study he will classify, scientifically, the causes of crime. His theology will teach him the results of a criminal career, and these results will be in accordance with his theological views; but his scientific classification must be based upon his scientific researches. He will find that, to some extent, men are criminals through their psycho-physical organization, and such a criminal commits crime without regard to his environment.

Prosperity, or the lack of prosperity, good or bad training, under all conditions, a man with an abnormal psycho-physical organization of a certain type not only commits crime, but defends it.

Another type of man, even with a normal psychophysical organization, commits crime through the influence of environment, or of an uneducated and an untrained conscience, or of a conscience naturally dull. The recent researches into the relation of the formation of the brain in certain parts to criminal tendencies are among the most valuable studies of scientific men; yet should their researches prove beyond doubt that certain brain formations

$$
[764]
$$


lead directly to criminal courses, such demonstration could not fully account for all criminal lives, in all degrees. If they did, there would be no use of wasting time over the discussion of the influence of heredity, environment, economic conditions, or of any of the other causes which, related or unrelated, lead men to criminal courses. Whatever cause the scientific criminologist may find and even establish, it is true, and must always be true, that a weak conscience will be lulled by necessity or desire to the point of criminal action, and that conditions surrounding a man will at times stimulate such action. Personally, I am very much in sympathy with the views of scientific criminologists, and with some of the views expressed by the celebrated Doctor Despine. I am rather out of sympathy with the idea that a criminal becomes such through the loss of moral attributes which he once possessed; with the idea that he started in life a comparatively good man, but that he has wilfully and maliciously broken the laws of the State. I believe the criminal is an undeveloped man in all his elements, whether you think of him as a worker or as a moral and intellectual being. His faculties are all undeveloped, not only those which enable him to labor honestly and faithfully for the care and support of himself and his family, but also all his moral and intellectual faculties. He is not a fallen being : he is an undeveloped individual.

The reverse of this idea leads men to adopt many illogical conclusions, and also leads into considering all the convicts of a State as belonging to the same class. Notwithstanding these statements, I believe it is true that men even with fairly sound consciences can and do become habituated to the idea of crime through their necessities or their environment, and even degenerate from a reasonably good life to a bad one. Such conditions have much to do with the commission of crime.

So while the scientific view of crime attracts me more than any other, I am yet aware that the penologist must [765] 
govern himself by the doctrine that men commit crime, or refrain from it, as they wish ; that crime is the result of some craving, some want, some unsatisfied desire, and that the basic action or motive of crime is to be found in some physical or mental condition. Whether it suits our views or not, therefore, we are obliged to consider the criminal as acting under free will, and while we need not lose sight of all the scientific conditions which are alleged as primarily necessary to constitute criminal action, we must deal with the criminal as a free, moral agent; as one committing his act to satisfy his want or desire, which he feels he is unable to satisfy through the ordinary or legitimate conditions. Hence the discussion of economic conditions in their relation to the causes of crime becomes legitimate.

All great social questions, on careful analysis, resolve themselves, in a more or less degree, into some phase of what we call the labor question, and certainly the causes of crime, in a sociological sense, cannot be studied without considering the status of man in the prevailing industrial order, for among all the causes for criminal action, or for the existence of the criminal class, we find that economic conditions contribute in some degree to their existence. This, however, is only a phase of criminology. It is this phase which has been given me as a subject for discussion.

The world has seen three great labor systems-labor under slavery, labor under the feudal system, and labor under the wage or the prevailing system. Crime was not so fully recognized under the slave and the feudal systems as it has been under the modern system of labor. Ownership came naturally through conquest. Possession was the clear title to property. Conflict and conquest were the prime causes of private ownership. Hence, under slavery, crime assumed a different relationship to the body-politic than it assumes under the modern system, where the right of free contract prevails. The feudal system was only an advanced phase of slavery, and so intermingled were the conditions that it is sometimes difficult to 
clearly define the life of the individual man under the two. These conditions existed prior to the general adoption of the wage system, and in the study of the relation of labor conditions to criminal conditions the earlier systems of labor become interesting. The peasants under the feudal system had no hope, for they had no land and no chance of bettering their condition. With no comforts or even necessaries of existence, life was to them a perpetual hardship. These conditions continued in many countries, the result usuaily being seen in vast herds of thieves, robbers, and vagrants that desolated the land. Even in the time of Henry VIII., and during the course of his reign of thirty-eight years, no fewer than seventy-two thousand persons were executed for crime. History has not begun to tell the story of the sufferings of labor prior to the advent of the modern industrial system, or of the necessities which drove men into criminal lives. All were in misery, with the exception of the few who constituted the families of the feudal lords. All the conditions surrounding labor were abject. Pauperism, as we understand it, was unknown, to be sure, because all were paupers. Pauperism, therefore, did not attract legislation, and crime, the offspring of pauperism and of idleness, was brutally treated; and these conditions, betokening an unsound social condition, existed until progress made pauperism and crime as well, the disgrace of a nation, and it was then that pauperism began to be recognized as a condition which might be relieved through legislation. Of course, intellectual growth began to have some influence. This is illustrated by one of the statutes of England passed against laborers during the worst days of her feudal labor, upon the complaint of lords and commons, and men of the Holy Church, who in their complaint state that " they do come there in great routs and agree by confederacy that every one shall aid every other to resist their lords with strong hands. And so they seemed, partly by law and partly by force, to resist all claims due of their 
bodies and of them as land-tenants." These efforts, marking the first results of intelligence among the laborers, constituted probably the first strikes for industrial progress in history. They were contemporaneous with those great upheavals on the continent which are traced up through the Anabaptist revolt and along up to the revolution of ' 89 , when the French nation sought to rid itself of the lingering burdens of feudalism; but it was through all these efforts in the great countries of Western Europe that the distinguishing features between prosperity and poverty became prominent. Carry industry to a country not given to mechanical production or to any systematic form of labor, employ threefourths of its inhabitants, give them a taste of education, of civilization, make them feel the power of moral forces even to a slight degree, and the misery of the other fourth can be gauged by the progress of the three-fourths, and a class of paupers and resultant criminals will be observed.

We have in our own day a most emphatic illustration of this in the emancipation of slaves in this country. Under the old system the negro slave was physically comfortable, as a rule. He was cared for, he was nursed in sickness, fed and clothed, and in old age his physical comforts were continued. He had no responsibility, and, indeed, exercised no skill beyond what was taught him. To eat, to work, and to sleep were all that was expected of him; and, unless he had a cruel master, he lived the life that belongs to the animal. Since his emancipation and his endowment with citizenship he has been obliged to support himself and his family, and to contend with all obstacles belonging to a person in a state of freedom. Under the system of villeinage in the old country it could not be said that there were any general poor, for the master and the lord of the manor took care of the laborers their whole lives; and in our Southern towns, during slavery, this was true, so that in the South there were few, if any, poorhouses, and few, if any, inmates of penal institutions. The South to-day knows what pauper- 
ism is, as England learned when the system of villeinage departed. Southern prisons have become active, and all that belongs to the defective, the dependent, and the delinquent classes has come to be familiar to the South.

To the industrial system, therefore, which was changed by the Civil War, the presence of some features of crime in the Southern States must be traced. The Civil War was, indeed, a labor war, whether it was instituted as such or not. The slave of the South could not compete with the skilled artisan of the North, and the conditions in the former had to give way to the conditions in the latter section of the country. The progress of the wage system, the increasing intelligence of the men who work under it will, as time advances, correct these crude conditions. They do not cause them : they only bring them into prominence. But so far as the modern industrial order superinduces idleness or unemployment, in so far it must be considered as having a direct relation to the causes of crime. I believe, however, that whatever tendency in this direction exists under the modern industrial order is of far less degree, not only in extent, but in severity, than the conditions which were superinduced by the industrial order which preceded it. In a treatise written by Richard Hakluyt, of England, in 1584 , on the religious, political, and commercial advantages to be derived by England from the attempted colonization of America, entitled "A Discourse on Westerne Plantinge," recently discovered, and published for the first time in 1877 , by the Maine Historical Society, the familiar question of how to employ the unemployed was discussed by the author, and in terms which remind one forcibly of the oft-repeated fears and the chimerical schemes of reformers of the present time.

In urging upon his government the undertaking of voyages, Hakluyt uses this language (the spelling being modernized), after referring to the prosperity of Spain and Portugal :

"But we, for all the statutes that hitherto can be devised, and the sharp execution of the same in punishing idle and 
lazy persons for want of sufficient occasion of honest employment, cannot deliver our commonwealth from multitudes of loiterers [tramps we call them], and idle vagabonds. Truth it is, that through our long peace and seldom sickness, two singular blessings of Almighty God, we are grown more populous than ever heretofore; so that now there are of every art and science so many that they can hardly live one by another; nay, rather, they are ready to eat up one another; yea, many thousands of idle persons are within this realm, which, having no way to be set on work, be either mutinous and seek alteration in the State, or, at least, very burdensome to the commonwealth, and often fall to pilfering and thieving and other lewdness, whereby all the prisons of the land are daily pestered and stuffed full of them, where either they pitifully pine away, or else at length are miserably hanged, even twenty at a clap out of some one jail. Whereas, if this voyage were put in execution, these petty thieves might be condemned for certain years in the western parts." And then follows a glowing picture of results, which the writer concludes as follows: "There need not one poor creature to steal, to starve, or to beg, as they do."

The quotation refers to a time only a quarter of a century prior to the permanent settlements on our coast, while in I629 John Winthrop, the first Governor of Massachusetts, before he left the old home, stated, among others, these reasons for leading emigrants out of the overburdened England, which Hakluyt described :

"This land grows weary of her inhabitants, so as man, who is the most precious of all creatures, is here more vile and base than the earth we tread upon, and of less price among us than a horse or a sheep. Many of our people perish for want of sustenance and employment; many others live miserably and not to the honor of so bountiful a housekeeper as the Lord of heaven and earth is, through the scarcity of the fruits of the earth. All of our towns complain of the 
burden of poor people, and strive by all means to rid any such as they have, and to keep off such as would come to them. I must tell you that our dear mother finds her family so overcharged as she hath been forced to deny harbor to her own children,--witness the statutes against cottages and inmates. And thus it is come to pass that children, servants, and neighbors, especially if they be poor, are counted the greatest burthens, which, if things were right, would be the chiefest earthly blessings."

These conditions of labor, as I have already stated, were all attended with a great volume of crime, and it was crime, to a large extent, which grew out of individual physical wants. Guizot has said that labor is a most efficient guarantee against the revolutionary disposition of the poorer classes. He might have added that labor, properly remunerated, is an effective guarantee against the commission of crime. Certainly hunger leads to more crime of a petty nature, perhaps, than any other one cause.

In the study of economic conditions, and whatever bearing they may have upon crime, I can do no better than to repeat, as a general idea, a statement made some years ago by Mr. Ira Steward, of Massachusetts, one of the leading labor reformers in that State in his day. He said: "Starting in the labor problem from whatever point we may, we reach, as the ultimate cause of our industrial, social, moral, and material difficulties, the terrible fact of poverty. By poverty we mean something more than pauperism. The latter is a condition of entire dependence upon charity, while the former is a condition of want, of lack, of being without, though not necessarily a condition of complete dependence."

It is in this view that the proper understanding of the subject given me, in its comprehensiveness and the development of the principles which underlie it, means the consideration of the abolition of pauperism and the eradication of crime; and the definitions given by Mr. Steward carry with them all the elements of those great special inquiries em- 
bodied in the very existence of our vast charitable, penal, and reformatory institutions, "How shall poverty be abolished, and crime be eradicated ?" The discussion is a very old one, and neither modern professional labor reformers, nor philanthropists, nor criminologists, nor penologists have any patents upon the theme: The progress of the world may be read as well by statutes in the humanity of law, in the existence of prisons, in the establishment of charitable institutions, and by the economic conditions which surround labor, as by written history; for, as the condition of labor rises, pauperism and crime must fall in the general scale.

To say that pauperism, and crime as an attendant evil, follow the unemployed more mercilessly than the employed, would be to make a statement too simple in its nature to invite serious consideration. Yet the history and the statistics of labor and the conclusions resulting from their study in their relation to pauperism and crime present most interesting and valuable features. Criminal conditions, the evils we are considering, have always existed, no matter what the social or legal status of men; under the most favorable as well as under the most unfavorable conditions ; under liberal and under despotic government; in barbarous and in enlightened lands; with heathenism and with Christianity; under a variety of commercial systems : and yet they are, in a philosophic sense, a rebuke to a people living under constitutional liberty.

Employment of the unemployed will not crush pauperism and crime, even if every able-bodied man in the country could be furnished with work to-morrow. Universal education will not. The realization of the highest hopes of the temperance and labor reformers will not. The general adoption of the Christian religion will not. But all these grand and divine agencies working together will reduce them to a minimum, and make that community which tolerates them indictable at the bar of public opinion, the most powerful tribunal known. 
Physical agencies, without all the higher elements, can do but little. The early history of this country and the history of all countries where civilization has made any headway teach this truth.

The proposition that pauperism and crime are less frequent in cultured communities will not, I suppose, be debated. It is true that the intelligent, skilled laborer is rarely found either in a penal or a charitable institution; nor is the person who has the elementary education sufficient to enable him to read, write, and make his own calculations so liable to become a charge as the one who has not these qualifications. I am, of course, aware that the full accuracy of these statements is oftentimes questioned; yet it is statistically true that enough of knowledge to be of value in increasing the amount and quality of work done, to give character, to some extent at least, to a person's tastes and aspirations, is a better safeguard against the inroads of crime than any code of criminal laws. I must, of course, consider this point as a fact, and shall not weary you with the oft-repeated arguments and the usual array of figures used to convince legislators that it is wise economy to foster our educational institutions. This being conceded as to intellectual or mental acquirements, including elementary book-learning, how does the fact affect the matter under consideration? Simply that the kind of labor which requires the most skill on the part of the workman to perform insures him most perfectly against want and crime, as a rule.

This statement is fortified by such statistics as are available. Of 4,340 convicts, at one time, in the State of Massachusetts, 2,991 , or 68 per cent, were returned as having no occupation.

The adult convicts numbered at that time 3,97I. Of these 464 were illiterate; and the warden of the State Prison, for the year in question, stated that of 220 men sentenced during that year, 147 were without a trade or any regular means of earning a living. 
In Pennsylvania, during a recent year, nearly 88 per cent of the penitentiary convicts had never been apprenticed to any trade or occupation; and this was also true of $68 \mathrm{I} / 2$ per cent of the convicts sentenced to county jails and workhouses in the same State during the same year.

In Mr. Frederick Wines' recent report on homicide in the United States, in 1890 , it is shown that of $6,95^{8}$ men, 5,175 , or more than 74 per cent of the whole, were said to have no trade.

The full statistics relating to convicts in the United States, when Mr. Wines makes his full report, will, I have no doubt, corroborate these statements.

These statistics represent the conditions in other latitudes, and show what is true everywhere, that it cannot be claimed that any very desirable working material can be found among convicts. If we except the large number that are unable to work, we shall by no means find workers remaining. We shall find some with trades, able and ready to work, but the greater number unpossessed of a self-supporting occupation, and many unwilling to work. I believe that the unfitness for productive labor, whether it springs from lack of a trade or occupation, or from personal antipathy to work, is a great and predisposing cause of both pauperism and crime. Furthermore, it is true, so far as the statistics which I have been able to consult demonstrate, that during periods of industrial depressions crime of almost all grades is increased in volume. The difficulty of demonstrating this feature of my subject to any full extent lies in the fact that our criminal statistics are given for periods, and not year by year. Could we have annual statements of the convictions. in all our States, so that such statements could be consulted relative to economic conditions, I feel sure that we should find a co-ordination of results that would startle us all. We should find that the lines of crime rise and fall as the prosperity of the country falls and rises.

The law of political economy comprehending supply and [774] 
demand is brought into prominence in this thought. It is an economic principle, always stated by all writers on political economy, that the highest cost makes the price. This is true only so long as demand is superior to supply. If the supply is superior to the demand, then the lowest cost makes the price in the market, and it is this condition that brings about what is popularly called "over-production," resulting in stagnation of trade and competition for work. This competition for work throws out the weaker elements in the industrial system, drives them to necessity, increases the want, and decreases the means of its satisfaction. Larceny, burglary, and all the forms of theft come into play, and the volume of crime increases. It is this principle, too, that influences the working man in his antagonism to the employment of convicts upon productive labor.

Political economists and all writers upon antagonistic commercial systems are fond of saying that if labor cannot be profitably employed at one trade or in one locality it should seek another. This was the favorite remedy offered by a certain class of political economists during all the great industrial depressions which existed in England during the first half of this century. Depression was to be relieved by a mobilization of labor. Now labor is not so mobile as these writers would have us believe. Great bodies of men employed in Lancashire in the cotton factories cannot, when sudden depressions come upon the industries, mobilize themselves so as to take up work in some other locality in England. The shutting down of the mines of Pennsylvania, or the reduction of work therein, throws large bodies of men out of employment, and it is utterly and physically impossible for those bodies of men to be mobilized or for them to take up other callings in life so as to keep the wolf from the door. These conditions make tramps. Crime is the result, and the criminal statistics swell into columns that make us believe that our social fabric is on the verge of ruin. Hungry stomachs, again, at such times, are at the base of 
the enlarged figures. Ignorance of work, the lack of some technical training prevents the mobilization of labor and compels men with a weak conscience to commit crime.

Doctor Schäffle, in his excellent work on the "Impossibility of Social Democracy," says : "We cannot do enough in the endeavor to abate and avoid the misery of these trade stoppages : it hangs like the sword of Damocles over the heads of non-propertied laborers; it embitters the existence of every one of them who reflects and who has the care and nurture of a family to provide for."

A11 idleness, whether induced by economic conditions, or by a lack of inclination to work, or by a lack of knowledge of how to work, leads directly to crime-not, of course, in all cases, but such conditions aggravate and irritate and drive men to criminal courses. The idle man's brain is, indeed, the devil's own workshop. Political economy, which has dealt so largely with the acquisition of wealth, must, sooner or later, deal with other features of wealth, and teach the world what conditions will largely relieve society of crime or largely lead to a reduction of its volume, through teaching the power of moral forces in the adjustment of industrial forces. My chief quarrel with political economy, which, to my mind, is one of the grandest departments of human knowledge, lies in this very thought, that it does not recognize as one of its elements the power of moral forces in society which really make or, mar healthy commercial conditions.

Under the new political economy, sanitary conditions are shown to be a necessity to true economic conditions. The material prosperity of a community depends much upon the health of its workers, and the health of workers depends in a very large degree upon sanitary surroundings. It is that the physical condition of the people may be improved by every means, that social economy deals with the subject of sewerage, tenement houses, light, and ventilation ; and in this respect social science teaches valuable lessons to political science, for the health of the workers of a [776] 
community is essential to their material prosperity, and the health of a community has much to do with the volume of crime.

In this connection I cannot refrain from weaving in a few thoughts from W. R. Greg, an English writer, with some of my own. Dwelling upon the physical and moral development of the race as essential to prosperity, it may be asked-What may we not rationally hope for when the condition of the masses shall receive that concentrated and urgent attention which has hitherto been directed to furthering the interests of more favored ranks? What, when charity, which for centuries has been doing mischief, shall begin to do good? What, when the countless pulpits, that so far back as history can reach, have been preaching Catholicism, or Anglicanism, Presbyterianism or Calvinism, or other isms, shall set to work to preach Christianity at last? Do we ever even approach to a due estimate of the degree in which every stronghold of vice or folly overthrown, exposes, weakens, and undermines every other? Of the extent to which every improvement, social, moral, or material, makes every other easier? Of the countless ways in which physical reform reacts on intellectual and ethical progress and the prosperity of our industries? Under the constant teaching of a moral philosophy which shall embrace the political economy of the labor question, what a transformation-almost a transfiguration-will spread over the condition of civilized communities, when, by a few generations, during which hygienic science and sense shall have been in the ascendant, the restored health of mankind shall have corrected the morbid exaggerations of our appetites; when, by insisting upon the lealthy environment of our toiling masses, the more questionable instincts and passions, which, under such rule as I have indicated, shall have been less and less exercised and stimulated for centuries perhaps, shall have faded into comparative quiescence, and have come under the control of the will; when, from 
the expulsion of vitiated air, disordered constitutions, whether diseased, criminal, or defective, which now spread and propagate so much mischief, and incur so much useless expense to taxpayers, shall have been largely eliminated; when sounder systems of educating the young shall have prevented the too early awakening of natural desires; when more rational, higher, and soberer notions of what is needful and desirable in social life, a wiser simplicity in living, and a more thorough conformity to moral law shall have rendered the legitimate gratification of our appetites more easy and beneficial, and when that which is needed for a happy home shall have become attainable by frugality, sobriety and toil! These conditions, so desirable to be reached, are not impossible ones, and are not to be reached by revolutionary schemes of any party or sect, but by the gradual adoption of sanitary laws in the dwellings and homes of the people; and the new school will teach that the secondary, and often the primary, causes and encouragements of intemperance are bad air and unwholesome food, which create a craving for drink ; bad company, which tempts it; undue facilities, which conduce to it; squalid homes, which drive men forth for cheerfulness; and the want of other comfortable places of resort, which leaves no refuge but the publican's parlor or den. And if, on the other hand, we find that the consequences are poverty, squalid homes, brutality, crime, and the transmission and perpetuation of vitiated constitutions, who can say they cannot be prevented by the sound administration of sanitary laws, which shall prohibit the existence of bad air, of unventilated dwellings, the undue multiplication and constant accessibility of gin and beer shops, and the poisoning of wholesome food and drink? You cannot discuss the labor question from either the ethical or economical side without consideration of the temperance question; and from the results of such consideration it is perfectly clear to my own mind that the solution of the temperance question is largely in 
the control of the employers of labor. The interests of capital as well as of labor, the interests of religion itself, demand a sober and industrious community; and, when the employers of labor shall demand abstinence from alcoholic drinks as a qualification for employment, the ugly problem, so far as the working masses are concerned, will be far on the way to settlement. What will bring the employers to the same issue is perhaps a knottier problem. The presence of crime works a direct injury upon the welfare of the workingman in many ways. It costs him more to live because of it; it disturbs his sense of justice because the convict works at the same occupation which furnishes his support; but, while the labor reformer cries for the abolition of convict labor, the political economy of the labor question cries for the reduction of the number of criminals by the prevention of crime as the surest and most permanent remedy for whatever evils may grow out of the practice of employing convicts in productive labor. We make criminals now ; for threefourths of the crime committed is by young men who are temporarily led astray, and the fact that fifty per cent of all the convicts in the States prisons of the United States are under twenty-six years of age only confirms the estimate. These accidental criminals we make into positive convicts, to be fed upon the production of men outside. We shall learn better methods in the future civil state, in which wise and effective legislation, backed by adequate administration resulting from a sound public sentiment, which will not hesitate to punish when necessary with that punishment which is most dreaded by the offender, shall have made all violation of law, all habitual crime, obviously, inevitably and instantly a losing game, and when the distribution of wealth, and its use, shall receive both from the statesman and the economist the same sedulous attention which is now concentrated exclusively upon its acquisition.*

* Professor F. A. Walker. 
It is perfectly true that unsanitary conditions, and all conditions that work a deterioration in the health of people, lead to uneconomic conditions. Bad air, bad housing, bad drainage, lead to intemperance and want. It requires no argument to show that these are precursors of crime. Anything that brings about a higher rate of mortality among the children of the poor leads to crime, and it is perfectly deducible from facts that are known that any occupation which insures a high rate of mortality among the children of its participants tends to conditions most favorable to the prevalence of pauperism and crime.

The displacement of labor through the application of improved machinery temporarily, and to the individual, produces a condition of want which may or may not be remedied by the increased labor demanded through invention. Society can be easily answered by stating the benefits which come to it through inventive genius, but it is a poor answer to the man who finds the means of supporting his family taken from him. But with the progress of invention and the consequent elevation of labor both pauperism and crime, so far as society is concerned, have correspondingly decreased. This is true in more senses than one. The age of invention, or periods given to the development and practical adaptation of natural laws, raises all peoples to a higher intellectual level, to a more comprehensive understanding of the world's. march of progress.

But the question of the removal of poverty and the suppression of crime is not wholly with the working man; the employer has as much to learn as he, and he is to be holden to equal, if not greater, responsibility. Ignorant labor comprehends ignorant employer. Insomuch as the profits of labor are equitably shared with labor, insomuch is poverty lessened, and, insomuch as poverty is lessened, insomuch is crime decreased. The employer should always remember that if conditions become ameliorated, if life becomes less of a struggle, if leisure be obtained, civilization, as a general 
rule, advances in the scale. If these conditions be reversed, if the struggle for existence tends to occupy the whole attention of each man, civilization disappears in a measure, * communities become dangerous and the people seek a revolutionary change, hoping by chance to secure what was not possible by honest labor.

In a State in which labor had all its rights there would be, of course, little pauperism and little crime. On the other hand, the undue subjection of the laboring man must tend to make paupers and criminals, and entail a financial burden upon wealth which it would have been easier to prevent than to endure; and this prevention must come in a large degree through educated labor.

Do not understand me as desiring to give the impression that I believe crime to be a necessary accompaniment of our industrial system. I have labored in other places and at other times to prove the reverse, and I believe the reverse to be true. Our sober, industrious working men and women are as free from vicious and criminal courses as any other class. What I am contending for, relates entirely to conditions affecting the few. The great volume of crime is found outside the real ranks of industry.

The modern system of industry has reduced the periods of depression from the long reaches extending over half a century under older systems. These periods have been reduced to decades and half decades of years. The time will come when periods of depression will occur only for the few months of a single year, and when this time comes the columns of the statistics of crime will show a receding quantity. Infinitely superior as the modern system is over that which has passed, the iron law of wages, when enforced with an iron hand, keeps men in the lowest walks of life, often on the verge of starvation. As intelligence increases and is more generally diffused, the individual man wants more, has higher aspirations for himself and his family ; but,

* Rawlinson's "Origin of Nations." 
under the iron law of wages, at times, all these desires and aspirations are hard to satisfy. The modern system produces mental friction; a competition of mind has taken the place, in a large measure, of mere muscular competition, and the laggard in the industrial race may lose his mind or his conscience, in the latter case causing him to develop into the criminal. The economic condition or environment of this particular man leads him inevitably to crime. But system gives way to system, and the present industrial order will be superseded by one vastly superior to it. As the establishment of the wage system reduced crime and its attendant evils, so that which is to come will still further benefit the human race ethically and economically.

Does some one inquire-Can it be possible that more civilization means more crime? Yes, and no. For a time under improved civilization, under improved mechanical methods, and under the march of invention, competition, as I have said, is mental to a larger degree than under the simpler methods and cruder civilization. The residuum of society is more easily observed and more thoroughly claims the attention of philanthropists and of legislators ; but to say that more civilization means more poverty and more crime is a reversal of truth in every sense. I believe that with elevated civilization there come conditions of labor which will largely relieve society of crime, or, at all events, largely reduce its volume. This imust come through a more just and a more equitable distribution of the profits of production. It has always proved true, and it always will prove true, that wherever there is a sincere desire to secure a just and equitable distribution of the rewards of production, or even to make headway in some measure, fruits, rich and abundant, have been the result. The experience of the Briggs brothers in their attempts at profit-sharing, converted a turbulent and intemperate community, given to theft and rioting, into a sober and orderly body of people. The experience of Robert Owen, at New Lanark, is the record of one of the most [782] 
prominent experiments in the Old World for the bettering of industrial communities. This experiment was made by Owen before he became imbued with socialism. At the period of his Lanark experience (1819), Owen gained respect and renown in distant lands, was sought by the great, was consulted by governments, and counted among his patrons princes of the blood in England, and more than one crowned head in Europe. The main cause of Owen's success began with the practical improvement of the working-people under his superintendence as manager, and afterward as owner of the cotton mills in New Lanark. He found himself surrounded by squalor, poverty, intemperance, and crime. He determined to change the whole condition of affairs. He erected healthy dwellings with adjacent gardens, and let them at cost price to the people. He adopted measures to put down drunkenness and to encourage the savings of the people. The employes became attached to their employer, took a personal interest in the success of the business, labored ably and conscientiously, and so made the mills of New Lanark, in Scotland, a great financial success. He tumed a community given much to law-breaking into one happy as a lawabiding people.

The experience of the Cheney brothers at South Manchester, Conn., of the Fairbanks Company in Vermont, of hundreds of others who have recognized the great fact of the Decalogue, testifies to the soundness of the thought that with improved conditions which result in economic environment, crime will be reduced.

All these considerations lead us to weigh well the practices which should be resorted to. Trade instruction, technical education, manual training-all these are efficient elements in the reduction of crime, because they all help to better and truer economic conditions. I think, from what I have said, the elements of solution are clearly discernible. Justice to labor, equitable distribution of profits under some system which, I feel sure will supersede the present, and without 
resorting to socialism; instruction in trades by which a man can earn his living outside a penal institution, the practical application of the great moral law in all business relationsall these elements, with the more enlightened treatment of the criminal when apprehended, will lead to a reduction in the volume of crime, but not to the millennium; for " human experience from time immemorial tells us that the earth neither was, nor is, nor ever will be, a heaven, nor yet a hell,"* but the endeavor of right-minded men and women, the endeavor of every government, should be to make it less a hell and more a heaven.

Washington.

Carrolit D. Wright.

* Dr. A. Shäffle. 